\title{
The effect of rework content addition on the microstructure and viscoelastic properties of processed cheese
}

\author{
Michaela Černíková, ${ }^{* 1}$ Jana Nebesářová,† Richardos Nikolaos Salek, ${ }^{*}$ Romana Popková, ${ }^{*}$ \\ and František Buňka* \\ *Department of Food Technology, Faculty of Technology, Tomas Bata University in Zlín, T.G. Masaryka 5555, 760 01, Zlín, Czech Republic \\ tLaboratory of Electron Microscopy, Institute of Parasitology, Biology Centre, Czech Academy of Science, v.v.i., Branišovská 31, 370 05, \\ České Budějovice, Czech Republic
}

\begin{abstract}
The aim of this work was to add various amounts of rework ( 0.0 to $20.0 \% \mathrm{wt} / \mathrm{wt}$ ) to processed cheeses with a dry matter content of $36 \%$ (wt/wt) and fat with a dry matter content of $45 \%$ (wt/wt). The effect of the rework addition on the viscoelastic properties and microstructure of the processed cheeses was observed. The addition of rework (in this case, to processed cheese with a spreadable consistency) in the amounts of 2.5, 5.0 , and $10.0 \%$ (wt/wt) increased the firmness of the processed cheese. With the further addition of rework, the consistency of the processed cheeses no longer differed significantly. The conclusions obtained by the measurement of viscoelastic properties were supported by cryo-scanning electron microscopy, where fat droplets in samples with added rework of over 10.0\% (wt/ wt) were smaller than fat droplets in processed cheeses with lower additions of rework.
\end{abstract}

Key words: processed cheese, rework, rheology, cryoscanning electron microscopy

\section{INTRODUCTION}

Processed cheeses (PC) are produced at an increased temperature and under moderate underpressure, from basic raw materials (cheeses, butter, water, emulsifying salts) to which other ingredients of a dairy or nondairy origin can be added. The consistency of PC is affected by several different factors, which we can divide into the following groups: (1) raw material composition (content of cheeses of various types and maturity, DM and fat in DM contents, concentration and composition of emulsifying salts, presence of hydrocolloids, rework content, and so on), (2) technological production parameters (agitation speed, agitation duration, cooling time and

Received August 25, 2017.

Accepted December 2, 2017.

${ }^{1}$ Corresponding author: cernikova@utb.cz rate, and so on), (3) storage conditions (storage length and temperature, packaging characteristics; Kapoor and Metzger, 2008; Salek et al., 2015; Černíková et al., 2017).

Rework is a PC that has already been processed once and in which creaming has already occurred; it is used as a raw material for the production of PC. Therefore, its consistency is affected by all of the aforementioned factors. Rework is created in the industry either (1) intentionally (production of $\mathrm{PC}$ for rework or residue of $\mathrm{PC}$ in production equipment) or (2) unintentionally (production of PC originally intended for the market network but ultimately not released for market; for example, due to unsuitable packaging or incorrect DM or fat in DM content). Rework is usually used fresh (PC residue in production equipment) or 3 to $14 \mathrm{~d}$ old (PC unsuitable for the market network due to unsuitable fat or DM content, or an incorrect packaging weight). Meyer (1973) and Guinee et al. (2004) defined 3 types of rework: (1) from young cheese with long protein chains (unripened raw material used for processing), (2) regular PC with a creamy structure, and (3) overcreamed product with a delicate structure. In Kaláb et al. (1987), 3 types of rework were also used: (1) fresh rework (produced and rapidly frozen immediately after production), (2) regular rework from previous processes, and (3) the so-called hot melt, which simulates PC subjected to extreme stress (cooled from 82 to $4^{\circ} \mathrm{C}$ in $5 \mathrm{~h}$ ), which Meyer (1973) refers to as overcreamed. All of the aforementioned types of reworks are processed under industrial conditions to prevent economic losses (Kaláb et al., 1987). The reasons for using rework can be economic (see above), but it is also used to increase viscosity (with the increasing age of the rework and with its increasing concentration) after production, increase firmness, improve meltability, or reduce the emulsifying salt content, as rework already contains emulsifying salt (Lauck, 1972; Meyer, 1973; Kaláb et al., 1987; Pluta et al., 2000; Kapoor and Metzger, 2008). However, individual types of reworks are added in different quantities for various reasons. 
If we use the division as per Meyer (1973), then fresh rework is used in a concentration of 1 to $2 \%$ (wt/wt) to increase the creaming of PC spreads, which contain a high proportion of ripened or very ripened cheeses in their raw material composition with intact casein content approximately $70 \%$, or more precisely, less than $65 \%$. The second type of rework (regular PC with a creamy structure) is used for block-type PC, to increase firmness and elasticity, in a quantity of 2 to $30 \%$ (wt/ wt). Meyer (1973) recommended that the third type of rework (over-creamed product with a delicate structure) be used only in a quantity of less than $1 \%$, as it has a very strong creaming effect and could easily lead to over-creaming. Lauck (1972) wrote about the addition of rework, usually in a quantity of 2 to $15 \%$ (wt/wt). Explanations of the applications of individual types of reworks are listed by Guinee et al. (2004), who claims that the additional heating of preprepared PC can cause a higher degree of temperature-induced dehydration and paracasein aggregation, particularly in the third type of rework (over-creamed product with a delicate structure), which increases the elasticity of the resulting product. The more effective dispersion of the emulsifying salts in rework (due to a longer contact period) leads to the faster hydration of paracasein and the high concentration of proteins, thanks to the high degree of emulsification and in the third type of rework (over-creamed product with a delicate structure), which leads to increased viscosity, the effective dispersion of fat, and the emulsification of the fresh melting mixture.

The literature has not described the effects of various concentrations of rework on the consistency of PC in detail, and in practice rework is added exclusively on the basis of empiricism. The aim of this study was to observe the effect of adding various quantities of rework to the raw material composition on the resulting consistency of the PC. Model samples with a DM content of $36 \%$ and fat in DM content of $45 \%$ were produced with an addition of $0.0,2.5,5.0,10.0,15.0$, and $20.0 \%$ (wt/wt) rework under industrial conditions. The consistency was examined using dynamic oscillatory rheometry over a 60 -d storage period. Individual analyses were performed on d 1, 7, 14, 30, and 60 after production.

\section{MATERIALS AND METHODS}

The model samples of PC were produced under industrial conditions, from raw materials manufactured by the PC producer. The following were used: Dutchtype cheese $[50 \%$ (wt/wt) DM content, $30 \%$ (wt/wt) fat in DM content, 8-wk maturity, Lacrum PLC, Velké Meziříćí, Czech Republic], unsalted butter [84\% (wt/ wt) DM content and $82 \%$ (wt/wt) fat content, Lacrum
PLC], water, emulsifying salts $[3 \%$ (wt/wt) calculated per total weight, composition of emulsifying salts (\% relative)]: $34 \% \mathrm{Na}_{2} \mathrm{HPO}_{4}, 26 \% \mathrm{NaH}_{2} \mathrm{PO}_{4}, 20 \% \mathrm{Na}_{4} \mathrm{P}_{2} \mathrm{O}_{7}$, and $20 \%$ sodium polyphosphate; Fosfa PLC, Břeclav, Czech Republic), and rework. The effect of individual emulsifying salts on $\mathrm{pH}$ shift in a model environment of deionized water, liquid dairy system, and PC was presented in Nagyová et al. (2014) and Salek et al. (2015). The rework added to the raw material composition was produced from the same raw material composition as the control sample (without the addition of rework) and added after $3 \mathrm{~d}$ of storage at a temperature of 6 $\pm 2^{\circ} \mathrm{C}(72 \mathrm{~h})$, in quantities of $0.0,2.5,5.0,10.0,15.0$, and $20.0 \%$ (wt/wt). The samples were produced using Stephan UM 130 equipment (Stephan Machinery GmbH, Hameln, Germany), at a melting temperature of $90^{\circ} \mathrm{C}$ (the holding time was 1 min and direct heating was used) and a blade revolution speed of 1,500 rpm. The total producing time was about 9 to $10 \mathrm{~min}$. Before the manufacture, slight underpressure was generated in the kettle (using a vacuum pump). Each PC with the certain rework concentration was manufactured 3 times $(3$ repetitions $\times 6$ concentrations of rework $=18$ manufactured batches). After production, the samples were packaged in plastic jars closed with lids, cooled to $6 \pm 2^{\circ} \mathrm{C}$, and stored for a period of 2 mo. The samples of each manufactured batch were analyzed after 1,7 , 14,30 , and $60 \mathrm{~d}$ of storage.

The DM content and the fat content of the PC samples were gravimetrically determined according to ISO 5534 (ISO, 2004a) and ISO 1735 (ISO, 2004b), respectively. The $\mathrm{pH}$ values were measured at ambient temperature using the glass tip electrode of a $\mathrm{pH}$ meter (pH Spear, Eutech Instruments Europe B.V., Landsmeer, the Netherlands), by directly inserting the spear into the PC samples in 3 randomly selected spots (in each packaging).

The rheological analysis of the PC samples was performed using a dynamic oscillatory shear rheometer (RheoStress 1, Haake, Bremen, Germany) with a plate-plate geometry (diameter $35 \mathrm{~mm}$, gap $1.0 \mathrm{~mm}$ ) at $20.0 \pm 0.1^{\circ} \mathbf{C}$. Storage $\left(\mathbf{G}^{\prime}\right)$ and loss $\left(\mathbf{G}^{\prime \prime}\right)$ moduli [determined as functions of frequency $(\omega)$ ranging from 0.1 to $100.0 \mathrm{~Hz}$ ] were monitored (shear stress amplitude $20 \mathrm{~Pa})$. The complex modulus $\left(\mathbf{G}^{*}\right)$ was calculated using the following formula:

$$
G^{*}=\sqrt{\left(G^{\prime}\right)^{2}+\left(G^{\prime \prime}\right)^{2}} .
$$

Increasing $G^{\prime}, G^{\prime \prime}$, and $G^{*}$ indicated the growing gel strength and firmness of the PC (Lee et al., 2004; Černíková et al., 2017). A frequency ( $\omega)$ of $1 \mathrm{~Hz}$ was chosen as the reference for the presentation of $\mathrm{G}^{*}$. Win- 
ter's critical gel theory was also implemented using the following equation (Gabriele et al., 2001):

$$
\mathrm{G}^{*}(\omega)=\mathrm{A}_{\mathrm{F}} \cdot \omega^{\frac{1}{\mathbf{z}}}
$$

where $A_{F}$ is the gel strength $\left(\mathrm{Pa} \cdot \mathrm{s}^{1 / \mathrm{z}}\right)$ and $\mathrm{z}$ is the interaction factor (defined as the number of structure units interacting with one another in a 3-dimensional network; unitless). The higher the interaction factor is, the more interactions occur in the matrix of the sample (Gabriele et al., 2001). Each sample was analyzed 3 times ( 3 repetitions $\times 3$ samples; $n=9$ ) and the results were expressed as median \pm standard deviation.

A Jeol JSM-7401F scanning electron microscope (Jeol, Tokyo, Japan) equipped with cryo-system ALTO 2500 (Gatan, Abingdon, UK) was used to study the microstructure of the model PC and distribution of fat globule size. Model PC samples were inserted in the sample holder, frozen rapidly with slush nitrogen, and transferred under vacuum to the cryo chamber of the Alto 2500 system, which was connected to the microscope. Here the sample was fractured at a temperature of $-135^{\circ} \mathrm{C}$ and a high vacuum (less than $10^{-4} \mathrm{~Pa}$ ). Then, the sample was moved into the scanning electron microscope cold stage and examined at $-135^{\circ} \mathrm{C}$. Each image was analyzed using ImageJ software (National Institutes of Health, Bethesda, MD). The photograph of each model sample was analyzed to determine the fat globule diameter $(\mu \mathrm{m})$. Each sample was analyzed twice $(3$ repetitions $\times 2$ samples; $n=6)$ and the results were expressed as median \pm standard error.

Kruskal-Wallis and Wilcoxon tests were used to evaluate the obtained results (the significance level was 0.05). For the estimation of $A_{F}$ and $z$, nonlinear regression analysis (the Marquardt-Levenburg method; $A_{F}>$ 0 and $z \geq 0$ ) was used. For the comparison of the fat globule distribution of samples with different rework concentration, chi-squared test was used. Unistat 6.5 software (Unistat, London, UK) and Microsoft Excel (Microsoft Corporation, Redmond, WA) were used for the statistical analysis.

\section{RESULTS AND DISCUSSION}

The DM content of individual processes cheeses fluctuated within a range of 36.31 to $36.68 \%$ (wt/wt; $P$ $\geq 0.05$ ), whereas the fat content was 16.3 to $16.5 \%$ (wt/wt; $P \geq 0.05$ ). The basic chemical parameters of the model samples are comparable; therefore, the samples can be evaluated in terms of the effect of the additions of various quantities of rework. The results of the $\mathrm{pH}$ measurements for all the samples during the $60-\mathrm{d}$ storage period are listed in Table 1. Within the scope of individual storage days, the $\mathrm{pH}$ values of samples with various quantities of added rework were comparable $(P \geq 0.05)$. During the 60 -d storage period, there was a slight decrease in $\mathrm{pH}(P<0.05)$, which was observed for these types of model samples in several works (Dimitreli and Thomareis, 2009; Weiserová et al., 2011; Salek et al., 2015). The explanation could lie in hydrolysis of phosphate salts or change of bonds of the compounds present and in the change of their dissociation (Dimitreli and Thomareis, 2009; Weiserová et al., 2011; Salek et al., 2015).

The results of the elastic $\left(\mathrm{G}^{\prime}\right)$ and loss $\left(\mathrm{G}^{\prime \prime}\right)$ moduli for individual model samples are listed in Figure 1 for d 1 and 60 of storage, at $6^{\circ} \mathrm{C}$, contingent on oscillation frequency $(0.1-100 \mathrm{~Hz})$. The rework is a PC produced in the usual manner (i.e., with a completed emulsification process) and already contains emulsifying salt; it has the ability to influence the functional properties of the resulting $\mathrm{PC}$ to which it is added during production. According to Kaláb et al. (1987), the addition of

Table 1. Results of $\mathrm{pH}$ measurement of model processed cheese manufactured with addition of rework after $1 \mathrm{~d}(24 \mathrm{~h}), 7 \mathrm{~d}, 14 \mathrm{~d}, 30 \mathrm{~d}$, and 60 $\mathrm{d}$ of storage and size of fat globules of model processed cheese after $60 \mathrm{~d}$ of storage ${ }^{1}$

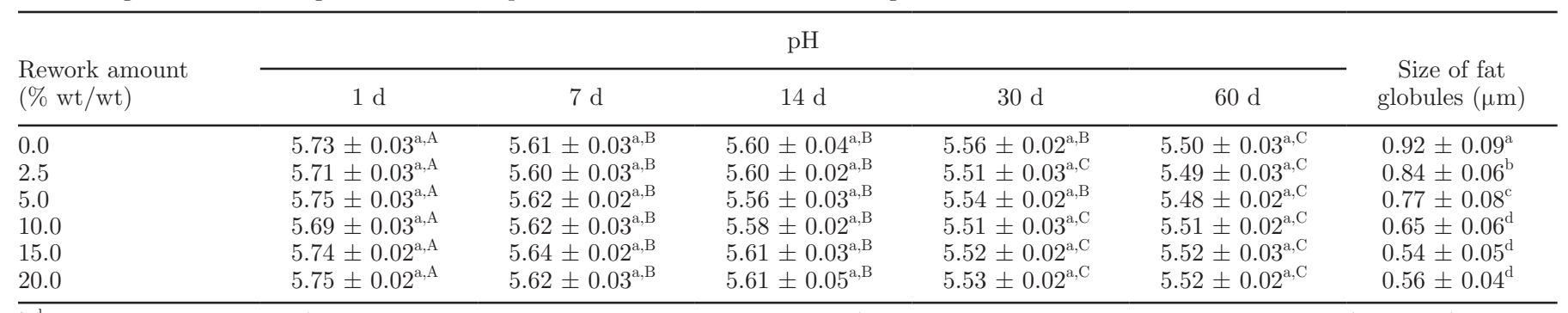

$\overline{\mathrm{a}-\mathrm{d}}$ Means within a column (the difference between the amount of rework added) followed by different lowercase letters differ $(P<0.05)$; samples stored during different times were evaluated independently.

${ }^{\mathrm{A}-\mathrm{C}}$ Means within a row (the difference between the storage time) followed by different uppercase letters differ $(P<0.05)$; samples manufactured using a different amount of rework were evaluated independently.

${ }^{1}$ Values were expressed as mean $\pm \mathrm{SD}$ (for $\mathrm{pH}$ values; $\mathrm{n}=9$ ) and mean $\pm \mathrm{SE}$ (for size of fat globules; $\mathrm{n}=6$ ). 
rework at a maximum quantity of $4 \%$ (wt/wt) does not affect the change in consistency of the final product. On the basis of the results presented in Figure 1 and the complex module $\left(\mathrm{G}^{*}\right)$ values and the gel strength values $\left(\mathrm{A}_{\mathrm{F}}\right)$ listed in Tables 2 and 3 , we can state that the addition of only $2.5 \%$ (wt/wt) rework has a significant $(P<0.05)$ effect on the change in consistency of the resulting $\mathrm{PC}$, whose firmness increases as a result of the added rework. Furthermore, we can state that a significant $(P<0.05)$ increase in firmness was observed until the addition of $10.0 \%$ (wt/wt) rework. With the addition of rework over $10.0 \%$ (wt/wt), the firmness of the produced $\mathrm{PC}$ no longer increased significantly $(P$ $\geq 0.05$ ). Through a more detailed comparison of individual model samples in Figure 1, we can say that, at lower frequencies and on the first day after production, PC produced without any addition of rework showed higher values $(P<0.05)$ in the loss module $\left(\mathrm{G}^{\prime \prime}\right)$ than in the elastic module $\left(G^{\prime}\right)$. It is assumed that if the values of $G^{\prime \prime}>G^{\prime}$, the intermolecular bonds in the melt (protein network) have sufficient time to weaken during the oscillation cycle. As the measurement frequency increased, the curves of the elastic and loss flexibility modules for a sample without added rework intersected. That is because, at higher frequencies, the intermolecular bonds no longer have sufficient time to weaken, so the PC behaves more like a solid (Cunha et al., 2013). A similar trend was also observed in $\mathrm{PC}$ with 2.5 and $5.0 \%$ (wt/wt) rework contents (Figure 1, A-C). However, we must point out that the intersection of both curves $\left(\mathrm{G}^{\prime}\right.$ and $\left.\mathrm{G}^{\prime \prime}\right)$ moved to lower frequencies $(P<0.05)$ as the rework content increased. Samples with added rework of $10.0 \%$ (wt/wt) and more (Figure 1, D-F) behaved more like solids at lower frequency measurements, as $\mathrm{G}^{\prime}>\mathrm{G}^{\prime \prime}$, which is characteristic of densely interconnected biopolymeric networks (Cunha et al., 2013). As the storage time lengthened, changes occurred in the matrix of the $\mathrm{PC}$ even without added rework. $\mathrm{G}^{\prime}$ and $\mathrm{G}^{\prime \prime}$ for $\mathrm{d} 60$ of storage are also listed in Figure 1. In the sample without added rework, the loss flexibility module $\left(\mathrm{G}^{\prime \prime}\right)$ once again prevailed at lower frequencies $(P<0.05)$, and the intersection of both curves $\left(\mathrm{G}^{\prime}\right.$ and $\left.\mathrm{G}^{\prime \prime}\right)$ occurred at lower frequencies than the first day after production (Figure 1, A). Therefore, at lower frequencies, the samples behaved more like a fluid than a solid. All samples with added rework from 2.5 to $20.0 \%$ (wt/wt) behaved like solids after $\mathrm{d} 60$ of storage, as their $\mathrm{G}^{\prime}$ showed higher values than $\mathrm{G}^{\prime \prime}$ for the entire period of measured frequencies (Figure $1, \mathrm{~B}-\mathrm{F})$. The aforementioned results are supported by the gel firmness values $\left(\mathrm{A}_{\mathrm{F}}\right)$ and the interaction factor (z) set forth in Tables 3 and 4. Gel firmness increased significantly even when only $2.5 \%$ (wt/wt) of rework was added $(P<0.05)$. At the same time, the value of the interaction factor increased $(P<0.05)$, which is evidence of the number of structural units interacting with one another in the protein network, or more precisely of the number of intermolecular bonds among the proteins. Thus, the increasing firmness of the gel was given by the increasing number of interactions in the 3-dimensional system studied (Macků et al., 2008, 2009; Cunha et al., 2013). Generally, the increase in the firmness of PC after the addition of rework was also described by Kaláb et al. (1987), who also stated that the firmest samples were ones with a "hot melt" content (heated for a longer period without mixing), whereas the softest samples were those without added rework. The work of Kaláb et al. (1987) also involved electron microscopy and stated that the greatest coalescence of fat occurred in hot melt samples. On the basis of the aforementioned results, we can state that regular PC with a creamy structure used as rework has a different effect on consistency and microstructure than rework in the form of an over-creamed product

Table 2. Values of complex modulus at reference frequency of $1 \mathrm{~Hz}\left(\mathrm{G}^{*} ; \mathrm{kPa}\right)$ of model processed cheese after $1 \mathrm{~d}(24 \mathrm{~h}), 7 \mathrm{~d}, 14 \mathrm{~d}, 30 \mathrm{~d}$, and $60 \mathrm{~d}$ of storage using different amounts of rework ${ }^{1}$

\begin{tabular}{|c|c|c|c|c|c|}
\hline $\begin{array}{l}\text { Rework amount } \\
(\% \text { wt/wt) }\end{array}$ & \multicolumn{5}{|c|}{$\mathrm{G}^{*}$} \\
\hline $\begin{array}{l}0.0 \\
2.5 \\
5.0 \\
10.0 \\
15.0 \\
20.0\end{array}$ & $\begin{array}{l}0.49 \pm 0.02^{\mathrm{a}, \mathrm{A}} \\
0.73 \pm 0.04^{\mathrm{b}, \mathrm{A}} \\
0.88 \pm 0.05^{\mathrm{c}, \mathrm{A}} \\
1.09 \pm 0.04^{\mathrm{d}, \mathrm{A}} \\
1.09 \pm 0.05^{\mathrm{d}, \mathrm{A}} \\
1.07 \pm 0.05^{\mathrm{d}, \mathrm{A}}\end{array}$ & $\begin{array}{l}0.58 \pm 0.02^{\mathrm{a}, \mathrm{B}} \\
0.91 \pm 0.03^{\mathrm{b}, \mathrm{B}} \\
1.21 \pm 0.05^{\mathrm{c}, \mathrm{B}} \\
1.32 \pm 0.06^{\mathrm{d}, \mathrm{B}} \\
1.30 \pm 0.04^{\mathrm{d}, \mathrm{B}} \\
1.36 \pm 0.06^{\mathrm{d}, \mathrm{B}}\end{array}$ & $\begin{array}{l}0.63 \pm 0.04^{\mathrm{a}, \mathrm{C}} \\
1.02 \pm 0.05^{\mathrm{b}, \mathrm{C}} \\
1.32 \pm 0.08^{\mathrm{c}, \mathrm{C}} \\
1.50 \pm 0.09^{\mathrm{d}, \mathrm{C}} \\
1.54 \pm 0.10^{\mathrm{d}, \mathrm{C}} \\
1.57 \pm 0.07^{\mathrm{d}, \mathrm{C}}\end{array}$ & $\begin{array}{l}0,70 \pm 0.04^{\mathrm{a}, \mathrm{D}} \\
1.07 \pm 0.06^{\mathrm{b}, \mathrm{C}} \\
1.37 \pm 0.05^{\mathrm{c}, \mathrm{C}} \\
1.63 \pm 0.10^{\mathrm{d}, \mathrm{D}} \\
1.61 \pm 0.06^{\mathrm{d}, \mathrm{C}} \\
1.73 \pm 0.12^{\mathrm{d}, \mathrm{D}}\end{array}$ & $\begin{array}{l}0.79 \pm 0.04^{\mathrm{a}, \mathrm{E}} \\
1.19 \pm 0.05^{\mathrm{b}, \mathrm{D}} \\
1.38 \pm 0.05^{\mathrm{c}, \mathrm{C}} \\
1.71 \pm 0.07^{\mathrm{d}, \mathrm{E}} \\
1.79 \pm 0.07^{\mathrm{d}, \mathrm{D}} \\
1.78 \pm 0.07^{\mathrm{d}, \mathrm{D}}\end{array}$ \\
\hline
\end{tabular}

\footnotetext{
${ }^{a-d}$ Means within a column (the difference between the amount of rework added) followed by different lowercase letters differ $(P<0.05)$; samples stored during different times were evaluated independently.

${ }^{\mathrm{A}-\mathrm{E}}$ Means within a row (the difference between the storage time) followed by different uppercase letters differ $(P<0.05)$; samples manufactured using a different amount of rework were evaluated independently.

${ }^{1}$ Values were expressed as mean $\pm \mathrm{SD}(\mathrm{n}=9)$.
} 


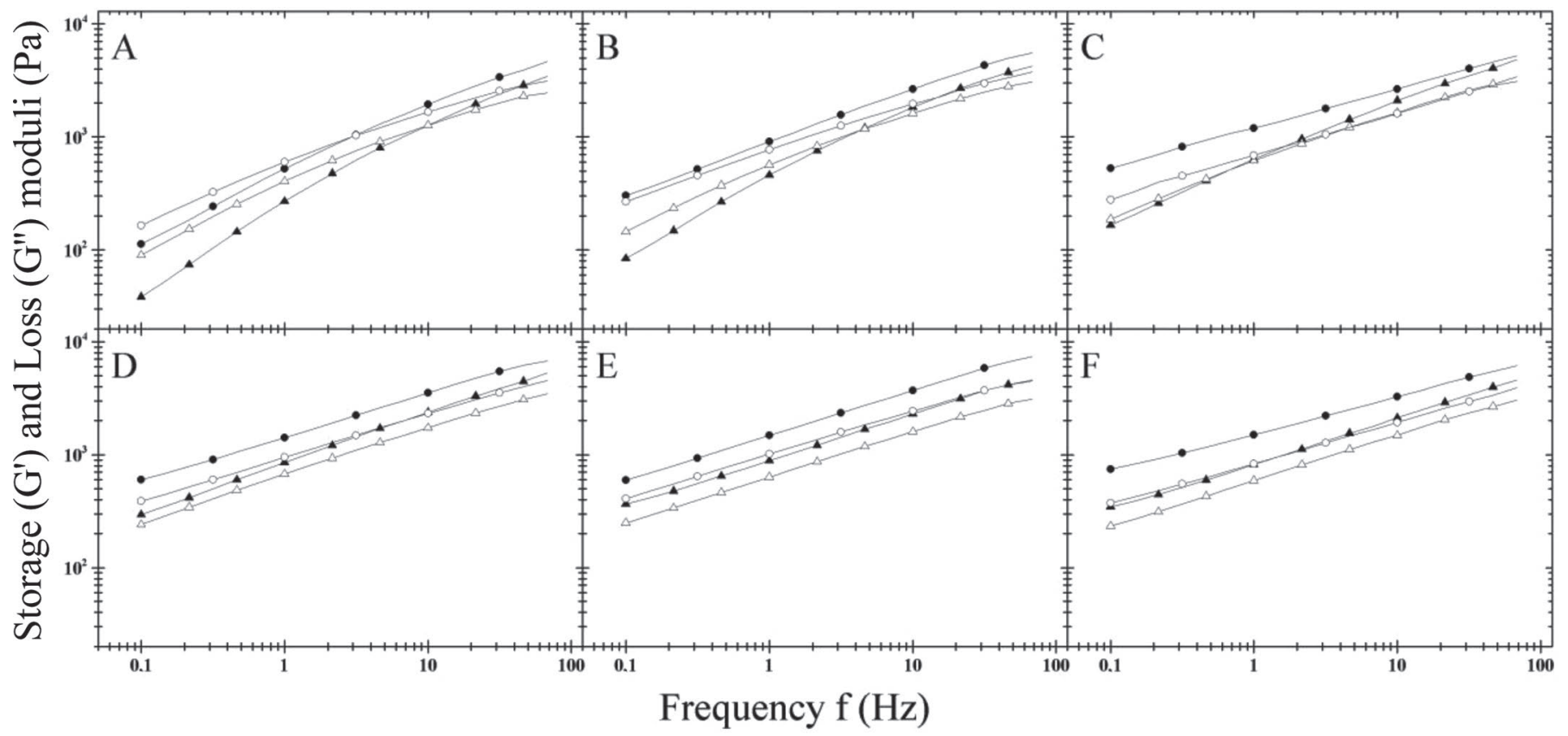

Figure 1. Dependence of the elastic ( $\mathrm{G}^{\prime}$; full symbols; $\left.\mathrm{Pa}\right)$ and the loss $\left(\mathrm{G}^{\prime \prime}\right.$; open symbols; Pa) moduli of the processed cheese spreads (36\% wt/wt in DM content; $45 \% \mathrm{wt} /$ wt fat in DM content) after $1 \mathrm{~d}(\Delta \Delta)$ and $60 \mathrm{~d}(\bullet \circ)$ of storage at $6 \pm 2^{\circ} \mathrm{C}$ on frequency (range of $0.1-100.0 \mathrm{~Hz}$ ). (A) $0.0 \%$ (wt/wt) rework, (B) 2.5\% (wt/wt) rework, (C) $5.0 \%$ (wt/wt) rework, (D) $10.0 \%$ (wt/wt) rework, (E) $15.0 \%$ (wt/wt) rework, and (F) $20.0 \%$ (wt/wt) rework.

with a delicate structure. The adding or replacing part of the raw material with rework increases the firmness and elasticity of the resulting product (Guinee et al., 2004).

Apart from the interconnectedness of the protein network evaluated by the interaction factor and gel firmness, the different consistencies of the $\mathrm{PC}$ with the addition of 2.5 to $10.0 \%$ (wt/wt) rework can also be explained by the varying sizes of the fat droplets (Figure 2 and Table 1). Statistically, the median value of fat droplets (Table 1) in a sample without added rework differed significantly from samples with added rework
$(P<0.05)$. Statistically, the addition of rework in a concentration of 10.0 to $20.0 \%$ (wt/wt; during mutual comparison) no longer significantly affected the size of the fat droplets $(P \geq 0.05)$. We could observe possible correlation between compactness of protein network and the gel strength $\left(\mathrm{A}_{\mathrm{F}}\right)$ and also the interaction factor $(\mathrm{z})$. With higher number of interaction factor we find out more compact protein matrix. The addition of rework affected the intensity of the emulsification of the present fat, which was demonstrated by the reduction in the size of the fat droplets. As the degree of fat emulsification grew, the firmness of the PC increased.

Table 3. Values of gel strength $\left(\mathrm{A}_{\mathrm{F}} ; \mathrm{kPa} \cdot \mathrm{s}^{1 / \mathrm{z}}\right.$, where $\mathrm{z}$ is the interaction factor) of model processed cheese after $1 \mathrm{~d}(24 \mathrm{~h}), 7 \mathrm{~d}, 14 \mathrm{~d}, 30 \mathrm{~d}$, and $60 \mathrm{~d}$ of storage using different amounts of rework ${ }^{1}$

\begin{tabular}{|c|c|c|c|c|c|}
\hline $\begin{array}{l}\text { Rework amount } \\
(\% \text { wt/wt) }\end{array}$ & \multicolumn{5}{|c|}{$\mathrm{A}_{\mathrm{F}}$} \\
\hline 0.0 & $0.56 \pm 0.03^{\mathrm{a}, \mathrm{A}}$ & $0.63 \pm 0.04^{\mathrm{a}, \mathrm{B}}$ & $0.70 \pm 0.03^{\mathrm{a}, \mathrm{C}}$ & $0.76 \pm 0.03^{\mathrm{a}, \mathrm{C}}$ & $0.87 \pm 0.04^{\mathrm{a}, \mathrm{D}}$ \\
\hline 5.0 & $0.94 \pm 0.04^{\mathrm{c}, \mathrm{A}}$ & $1.28 \pm 0.07^{\mathrm{c}, \mathrm{B}}$ & $1.35 \pm 0.09^{\mathrm{c}, \mathrm{B}}$ & $1.44 \pm 0.07^{\mathrm{c}, \mathrm{C}}$ & $1.38 \pm 0.06^{\mathrm{c}, \mathrm{BC}}$ \\
\hline 10.0 & $1.12 \pm 0.07^{\mathrm{d}, \mathrm{A}}$ & $1.39 \pm 0.06^{\mathrm{d}, \mathrm{B}}$ & $1.50 \pm 0.07^{\mathrm{d}, \mathrm{C}}$ & $1.60 \pm 0.09^{\mathrm{d}, \mathrm{C}}$ & $1.77 \pm 0.10^{\mathrm{d}, \mathrm{D}}$ \\
\hline 15.0 & $1.15 \pm 0.05^{\mathrm{d}, \mathrm{A}}$ & $1.30 \pm 0.06^{\mathrm{cd}, \mathrm{B}}$ & $1.55 \pm 0.11^{\mathrm{d}, \mathrm{C}}$ & $1.58 \pm 0.08^{\mathrm{d}, \mathrm{C}}$ & $1.85 \pm 0.09^{\mathrm{d}, \mathrm{D}}$ \\
\hline
\end{tabular}

${ }^{\mathrm{a}-\mathrm{d}}$ Means within a column (the difference between the amount of rework added) followed by different lowercase letters differ $(P<0.05)$; samples stored during different times were evaluated independently.

${ }^{\mathrm{A}-\mathrm{E}}$ Means within a row (the difference between the storage time) followed by different uppercase letters differ $(P<0.05)$; samples manufactured using a different amount of rework were evaluated independently.

${ }^{1}$ Values were expressed as mean $\pm \mathrm{SD}(\mathrm{n}=9)$. 
Table 4. Values of interaction factor $(\mathrm{z})$ of model processed cheese after $1 \mathrm{~d}(24 \mathrm{~h}), 7 \mathrm{~d}, 14 \mathrm{~d}, 30 \mathrm{~d}$, and $60 \mathrm{~d}$ of storage using different amounts of rework ${ }^{1}$

\begin{tabular}{|c|c|c|c|c|c|}
\hline \multirow{2}{*}{$\begin{array}{l}\text { Rework amount } \\
(\% \mathrm{wt} / \mathrm{wt})\end{array}$} & \multicolumn{5}{|c|}{ Z } \\
\hline & $1 \mathrm{~d}$ of storage & $7 \mathrm{~d}$ of storage & $14 \mathrm{~d}$ of storage & $30 \mathrm{~d}$ of storage & $60 \mathrm{~d}$ of storage \\
\hline$\overline{0.0}$ & $2.05 \pm 0.15^{\mathrm{a}, \mathrm{A}}$ & $2.09 \pm 0.11^{\mathrm{a}, \mathrm{A}}$ & $2.16 \pm 0.09^{\mathrm{a}, \mathrm{B}}$ & $2.20 \pm 0.13^{\mathrm{a}, \mathrm{B}}$ & $2.23 \pm 0.07^{\mathrm{a}, \mathrm{BC}}$ \\
\hline 2.5 & $2.23 \pm 0.12^{\mathrm{b}, \mathrm{A}}$ & $2.31 \pm 0.11^{\mathrm{b}, \mathrm{B}}$ & $2.34 \pm 0.09^{\mathrm{b}, \mathrm{B}}$ & $2.42 \pm 0.13^{\mathrm{b}, \mathrm{C}}$ & $2.47 \pm 0.12^{\mathrm{b}, \mathrm{C}}$ \\
\hline 5.0 & $2.27 \pm 0.16^{\mathrm{b}, \mathrm{A}}$ & $2.43 \pm 0.14^{\mathrm{bc}, \mathrm{B}}$ & $2.53 \pm 0.14^{\mathrm{c}, \mathrm{C}}$ & $2.61 \pm 0.11^{\mathrm{c}, \mathrm{D}}$ & $2.83 \pm 0.18^{\mathrm{c}, \mathrm{E}}$ \\
\hline 10.0 & $2.42 \pm 0.09^{\mathrm{d}, \mathrm{A}}$ & $2.48 \pm 0.15^{\mathrm{c}, \mathrm{A}}$ & $2.86 \pm 0.10^{\mathrm{d}, \mathrm{B}}$ & $2.93 \pm 0.15^{\mathrm{d}, \mathrm{B}}$ & $2.71 \pm 0.18^{\mathrm{c}, \mathrm{B}}$ \\
\hline 15.0 & $2.64 \pm 0.13^{\mathrm{e}, \mathrm{A}}$ & $2.45 \pm 0.12^{\mathrm{c}, \mathrm{A}}$ & $2.86 \pm 0.10^{\mathrm{d}, \mathrm{B}}$ & $2.93 \pm 0.12^{\mathrm{d}, \mathrm{B}}$ & $2.68 \pm 0.13^{\mathrm{c}, \mathrm{A}}$ \\
\hline 20.0 & $2.50 \pm 0.14^{\mathrm{de}, \mathrm{A}}$ & $2.56 \pm 0.13^{\mathrm{d}, \mathrm{A}}$ & $2.86 \pm 0.14^{\mathrm{d}, \mathrm{B}}$ & $2.93 \pm 0.14^{\mathrm{d}, \mathrm{C}}$ & $2.92 \pm 0.18^{\mathrm{d}, \mathrm{C}}$ \\
\hline
\end{tabular}

${ }^{\mathrm{a}-\mathrm{e}}$ Means within a column (the difference between the amount of rework added) followed by different lowercase letters differ $(P<0.05) ;$ samples stored during different times were evaluated independently.

${ }^{\text {A-E }}$ Means within a row (the difference between the storage time) followed by different uppercase letters differ $(P<0.05)$; samples manufactured using a different amount of rework were evaluated independently.

${ }^{1}$ Values were expressed as mean $\pm \mathrm{SD}(\mathrm{n}=9)$.

This phenomenon corresponds to the results of the works of Kapoor and Metzger (2008), Lee et al. (2015), and Černíková et al. (2017). With higher additions of rework (above 10.0\% wt/wt), no further changes in the fat droplets or viscoelastic properties were observed in our work. On the other hand, Kaláb et al. (1987), who used block-type PC with a higher DM content (55\% $\mathrm{wt} / \mathrm{wt}$ ) for their experiment, observed structure and consistency changes in products manufactured with the rework content higher than $10.0 \%$ (wt/wt).

\section{CONCLUSIONS}

This work studied the effect of rework content at an age of $72 \mathrm{~h}$ on the consistency of PC. It was discovered that a lower quantity of added rework, up to $10.0 \%$ (wt/ wt), caused a gradual increase in the firmness of the PC; simultaneously, the size of the fat droplets gradually decreased, which results primarily from the improvement of the emulsification properties as the amount of rework added increases. As the rework concentration in
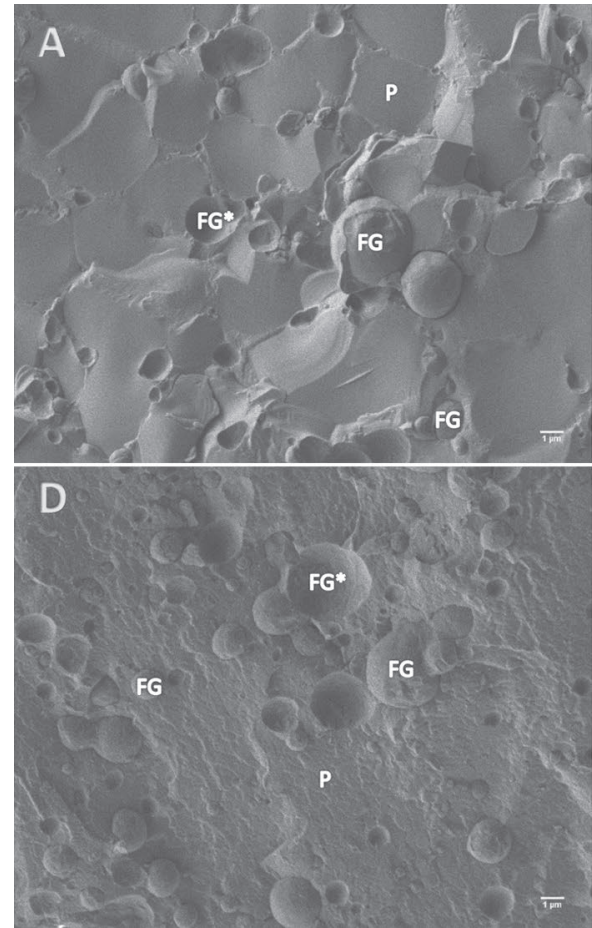
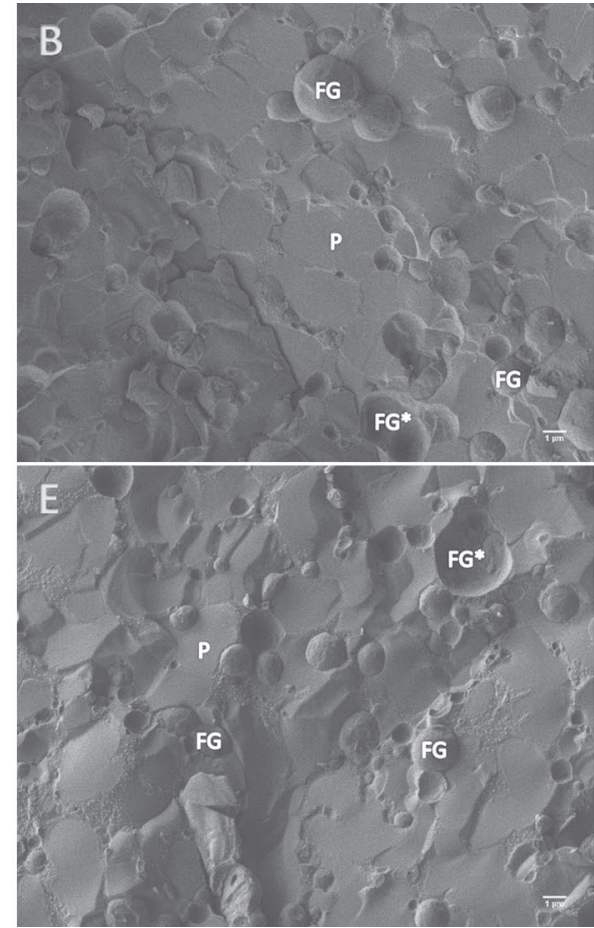
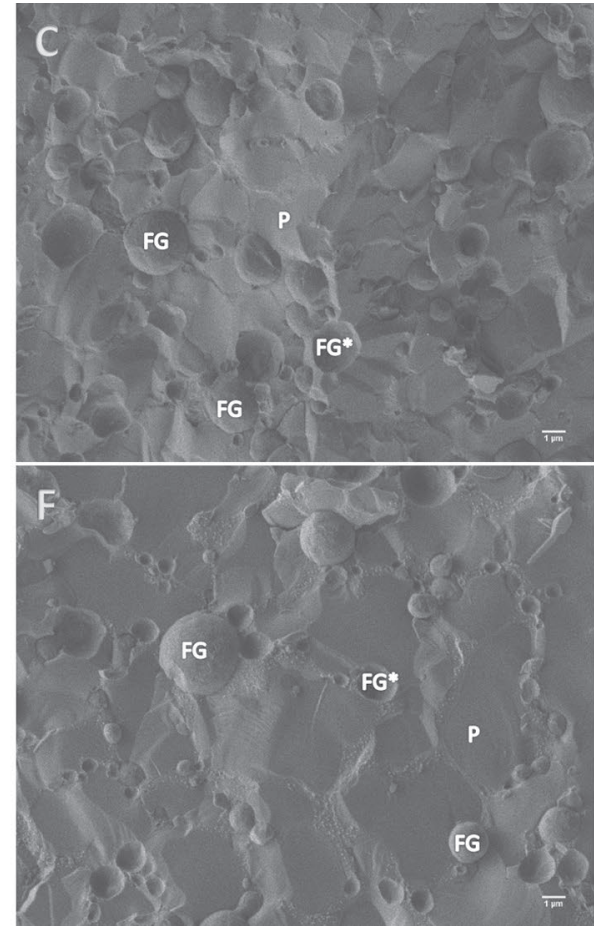

Figure 2. Scanning electron microscopy images of model processed cheese with different rework content. (A) $0.0 \%$ (wt/wt) rework, (B) $2.5 \%$ (wt/wt) rework, (C) 5.0\% (wt/wt) rework, (D) 10.0\% (wt/wt) rework, (E) $15.0 \%$ (wt/wt) rework, and (F) 20.0\% (wt/wt) rework. FG = fat globule; $\mathrm{FG}^{*}=$ removed fat globule; $\mathrm{P}=$ protein phase. Scale bar $=1 \mu \mathrm{m}$. 
the raw material composition increased further (from $10.0-20.0 \% \mathrm{wt} / \mathrm{wt}$ ), the firmness of the PC no longer increased, and the median size value of the fat droplets, which was smaller than that in samples with less added rework, also no longer differed significantly.

\section{ACKNOWLEDGMENTS}

This study was kindly supported by a project of the internal grants of Tomas Bata University in Zlin, Czech Republic, no. IGA/FT/2018/003, funded from the resources of specific university research. We acknowledge the core facility Laboratory of Electron Microscopy, Biology Centre of Czech Academy of Science, České Budejovice, supported by the Ministry of Education, Youth and Sports of the Czech Republic (LM2015062 Czech-BioImaging, Prague, Czech Republic).

\section{REFERENCES}

Černíková, M., J. Nebesářová, R. N. Salek, L. Řiháčková, and F. Buňka. 2017. Microstructure, textural and viscoelastic properties of model processed cheese with different dry matter and fat in dry matter content. J. Dairy Sci. 100:4300-4307. https://doi.org/10 $.3168 /$ jds.2016-12120.

Cunha, C. R., R. Grimaldi, M. R. Alcantara, and W. H. Viotto. 2013 Effect of the type of fat on rheology, functional properties and sensory acceptance of spreadable cheese analogue. Int. J. Dairy Technol. 66:54-62. https://doi.org/10.1111/j.1471-0307.2012.00876.x.

Dimitreli, G., and A. S. Thomareis. 2009. Instrumental textural and viscoelastic properties of processed cheese as affected by emulsifying salts and in relation to its apparent viscosity. Int. J. Food Prop. 12:261-275. https://doi.org/10.1080/10942910802256164.

Gabriele, D., B. de Cindio, and P. D'Antona. 2001. A weak gel model for foods. Rheol. Acta 40:120-127. https://doi.org/10.1007/ s003970000139.

Guinee, T. P., M. Carić, and M. Kaláb. 2004. Cheese: Pasteurized processed cheese and substitute/imitation cheese products. Pages 349-393 in Cheese: Chemistry, Physics and Microbiology, Volume 2: Major Cheese Group. 3rd ed. P. F. Fox, P. L. H. McSweeney, and T. P. Cogan, ed. Elsevier Applied Science, London, UK.

ISO (International Organization for Standardization). 2004a. ISO Standard No. 5534: Cheese and processed cheese-Determination of the total solid content (reference method). ISO, Geneva, Switzerland.
ISO (International Organization for Standardization). 2004b. ISO Standard No. 1735: Cheese and processed cheese products-Determination of fat content-Gravimetric method (reference method). ISO, Geneva, Switzerland.

Kaláb, M., J. Yun, and S. H. Yiu. 1987. Textural properties and microstructure of process cheese food rework. Food Microstruct. $6: 181-192$

Kapoor, R., and L. E. Metzger. 2008. Process cheese: Scientific and technological aspects-A review. Comp. Rev. Food Sci. Saf. 7:194214. https://doi.org/10.1111/j.1541-4337.2008.00040.x.

Lauck, R. M., inventor; Stauffer Chemical Co., assignee. 1972. Using salvage cheese in preparing pasteurized process cheese. New York. US patent 3,697,292.

Lee, S. K., S. Anema, and H. Klostermeyer. 2004. The influence of moisture content on the rheological properties of processed cheese spreads. Int. J. Food Sci. Technol. 39:763-771. https://doi.org/10 $.1111 /$ j.1365-2621.2004.00842.x.

Lee, S. K., H. Klostermeyer, and S. G. Anema. 2015. Effect of fat and protein-in-water concentration on the properties of model processed cheese. Int. Dairy J. 50:15-23. https://doi.org/10.1016/ j.idairyj.2015.06.001.

Macků, I., F. Buňka, V. Pavlínek, P. Leciánová, and J. Hrabě. 2008 The effect of pectin concentration on viscoelastic and sensory properties of processed cheese. Int. J. Food Sci. Technol. 43:16631670. https://doi.org/10.1111/j.1365-2621.2008.01734.x.

Macků, I., F. Buňka, B. Voldánová, and V. Pavlínek. 2009. Effect of addition of selected solid cosolutes and pectin on viscoelastic properties of model processed cheese. Food Hydrocoll. 23:2078-2084. https://doi.org/10.1016/j.foodhyd.2009.03.020.

Meyer, A. (1973). Processed cheese Manufacture, Food Trade Press ltd., London.

Nagyová, G., F. Buňka, R. N. Salek, M. Černíková, P. Mančík, T. Grůber, and D. Kuchař. 2014. Usage of sodium polyphosphates with different linear length in the production of spreadable processed cheese. J. Dairy Sci. 97:111-122. https://doi.org/10.3168/ jds.2013-7210.

Pluta, A., M. Ziarno, and A. Smolińska. 2000. Możliwości zastosowania hydrokoloidów w produkcji serów topionych. Premysl Spożywczy. 5:42-44.

Salek, R. N., M. Černíková, G. Nagyová, D. Kuchař, H. Bačová, L. Minarčíková, and F. Buňka. 2015. The effect of ternary mixtures composition containing phosphate and citrate emulsifying salts on selected textural properties of spreadable processed cheese. Int Dairy J. 44:37-43. https://doi.org/10.1016/j.idairyj.2014.12.009.

Weiserová, E., L. Doudová, L. Galiová, L. Žák, J. Michálek, R. Janiš, and F. Buňka. 2011. The effect of combinations of sodium phosphates in binary mixtures on selected texture parameters of processed cheese spreads. Int. Dairy J. 21:979-986. https://doi.org/10 .1016/j.idairyj.2011.06.006. 